\title{
POLITIK HUKUM PIDANA DALAM KEJAHATAN PERKOSAAN
}

Sabar Slamet

Fakultas Hukum Universitas Sebelas Maret

email :sabarslamet56@gmail.com

\begin{abstract}
Rape crime is a form of crime against women. In its development, this crime can no longer be seen as merely moral offence, however it had touched the problem of anger and violence considered as violation and denial against human rights. Considering this development, the Drafting Team of KUHP Barn should change the formulation of rape crime law, the definition of which no longer exists in the article 285 of KUHP (penal code) but it should be extended in order to be consistent with development and future condition. Through policy or penal code politics, the more adequate law formulation about rape crime would be achieved, consistent with the time condition.
\end{abstract}

Keywords : Criminal Law Politics, Crime, Rape

Abstrak

Tindak pidana perkosaan merapakan salah satu bcntuk kejahatan kekerasan terhadap wanita. Dalam perkembangannya tindak pidana ini tidak lagi dilihat sebagai persoalan moral semata-mata (moral offence), namun di dalamnya sudah menyentuh pada masalah anger and violence yang dianggap merupakan pelanggaran dan pengingkaran HAM. Mendasarkan perkembangan ini Tim Perancang KUHP Baru memandang perlu untuk mengubah rumusan tindak pidana perkosaan, yaitu tidak lagi pengertiannya seperti yang ada dalam rumusan Pasal 285 KUHP tetapi diperluas sesuai dengan perkembangan dan keadaan di masa mendatang,. Melalui kebijakan atau politik hukum pidana dapat dicapai rumusan tindak pidana perkosaan yang lebih memadai dengan keadaan zaman.

Kata kunci : Politik hukum pidana, Kejahatan, Perkosaan.

\section{A. Pendahuluan}

Dengan berpegang pada alasan politis, sosiologis dan praktis, kehendak untuk menggantikan KUHP dengan KUHP Baru, sesungguhnya sudah dimulai sejak tahun 1977. Dalam pembentukan konsep KUHP baru sampai pada tahap Rancangan KUHP Baru sebagai pengganti KUHP ternyata memerlukan proses yang cukup panjang. Dalam kurun waktu tersebut telah terjadi pula beberapa kali perubahan yang terkait dengan penambahan tindak pidana baru baik yang semula tidak ada di dalam dan di luar KUHP maupun diambil dari tindak pidana yang sudah ada dan tersebar di luar KUHP sebagai langkah penyempurnaan untuk menuju pada bentuk Rancangan KUHP Baru. 
Untuk menyeleksi peraturan hukum pidana yang sudah ada, terutama yang terkait dengan dekriminalisasi, patokan kebijakannya masih memperhatikan pada Pasal V Undang-Undang No. 1 tahun 1946 yaitu apabila peraturan yang sudah ada itu :

a. tidak dapat dijalankan;

b. bertentangan dengan kedudukan RI sebagai negara merdeka; dan,

c. tidak mempunyai arti lagi.

Sedang sumber bahan dalam kebijakan melakukan perubahan dan penyusunan tindak pidana baru diambil antara lain dari :

a. masukan berbagai pertemuan ilmiah (simposium/seminar/lokakarya) yang berarti juga dari berbagai kalangan masyarakat luas ;

b. masukan dari beberapa hasil penelitian dan pengkajian mengenai perkembangan beberapa tindak pidana khusus dalam masyarakat dan perkembangan iptek;

c. masukan dari pengkajian dan pengamatan bentuk - bentuk serta dimensi baru kejahatan dalam pertemuan - pertemuan kongres internasional;

d. masukan dari berbagai konvensi internasional (baik yang telah diratifikasi maupun yang belum diratifikasi); dan.

e. masukan dari hasil pengkajian perbandingan berbagai KUHP asing. Karena itu Crime stimulation policy dalam KUHP mendatang cukup kompleks. Hal-hal yang dipertimbangkan cukup banyak baik dari segi politik, ekonomi, sosial budaya, bahkan, perkembangan teoretis dan empiris dalam bidang hukum pidana, aspek ideologi nasional, kondisi manusia, alam serta tradisi bangsa dan yang tidak kalah pentingnya adalah kecenderungan - kecenderungan internasional yang diakui oleh masyarakat beradab. Studi perbandingan hukum menjadi sangat penting dan pendekatan deduktif - hipotetis dan induktif - empiris harus dilakukan secara terpadu (Muladi, 1993). 
Metode dalam pembaruan hukum (Rancangan KUHP) yang digunakan adalah metode evolusioner dalam arti melakukan perbaikan, penyempurnaan dan amandemen terhadap peraturan -peraturan yang sudah ada dalam KUHP atau dengan metode kompromis yakni dengan menambahkan bab tersendiri mengenai tindak - tindak pidana tertentu. Sebagai contoh adalah bab tentang Tindak Pidana terhadap Penyelenggaraan Peradilan dan bab tentang Tindak Pidana terhadap Agama dan Kehidupan Keagamaan (Muladi, 1993).

Namun perlu dipahami, bahwa seluruh langkah dan pemikiran dalam proses pcmbcntukan Rancangan KUHP diatas sesungguhnya lebih merupakan persoalan tentang Kebijakan Pidana atau Politik Hukum Pidana. Menurut Sudarto (1983), melaksanakan Politik Hukum Pidana berarti usaha mewujudkan peraturan perundang-undangan pidana yang sesuai dengan keadaan dan situasi pada suatu waktu serta untuk masamasa yang akan datang. Senada dengan itu dikuatkan pula dalam kesempatan lain, bahwa melaksanakan Politik Hukum Pidana berarti mengadakan pemilihan untuk mencapai hasil perundangan pidana yang paling baik dalam arti memenuhi syarat keadilan dan dayaguna (Sudarto, 1981).

Kebijakan Pidana di atas mencakup baik pengetahuan maupun seni, yang terutama berusaha untuk mencapai tujuan-tujuan praktis, yang memungkinkan peraturan-peraturan positif dirumuskan lebih baik dan memberikan panduan tidak hanya bagi pembuat undang-undang, tetapi juga bagi pengadilan yang menerapkan undang-undang tersebut dan bagi aparat koreksi (correctional agency), yang menjadikan putusan-putusan pengadilan mempunyai efek praktis (Muladi, 1990).

Karena itu, usaha dan kebijakan untuk membuat peraturan hukum pidana yang baik pada hakikatnya tidak dapat dilepaskan dari tujuan penanggulangan kejahatan. Jadi kebijakan atau politik hukum pidana juga merupakan bagian dari politik kriminal, oleh karena itu politik hukum 
pidana identik dengan pengertian "kebijakan penanggulangun kejahatan dengan hukum pidana" (Ariel': Tanpa tahun).

Selanjutnya, apabila Kebijakan atau Politik Hukum Pidana tersebut dihu-bungkan dengan hasil rumusan-rumusan tindak pidana yang terdapat dalam Rancangan KUHP Baru, maka yang cukup menarik mendapatkan perhatian dalam tulisan ini adalah masalah kejahatan kesusilaan khususnya tentang "perkosaan". Hal ini disebabkan pengertian "tindak pidana perkosaan" dalam Rancangan KUHP Baru telah mengalami pengembangan dan perluasan sedemikian rupa sehingga tindak pidana perkosaan bukan hanya diartikan sebatas "persetubuhan di luar perkawinan yang dilakukun secara paksa terhadap seorang wanita" sebagaimana yang diatur dalam Pasal 235 KUHP.

Akhirnya berangkat dari rasa ketertarikan terhadap perluasan pengertian perkosaan yang ada dalam Rancangan KUHP Baru, dalam pembahasan selanjutnya akan disampaikan uraian mengenai; "Apakah yang menjadi pertimbangan sehingga tindak pidana perkosaan perlu diperluas dalam rumusan KUHP mendatang?", dan "bagaimana batasan rumusan delik perkosaan antara KUHP dengan Rancangan KUHP Baru beserta implikasinya?".

\section{B. Kejahatan Perkosaan dalam Perspektif KUHP Nasional}

Pelaksanaan kebijakan atau politik hukum pidana dalam rangka penciptaan KUHP Baru di Indonesia, selain mendasarkan pada ketiga alasan (politis, Sosiologis, Praktis), yang perlu mendapatkan perhatian lagi dari sisi kajian komprehensif' adalah alasan adaptif yaitu bahwa KUHP nasional di masa mendatang harus dapat menyesuaikan diri dengan perkembangan-perkembangan baru, khususnya perkembangan internasional yang sudah disepakati oleh masyarakat beradab. Perkembangan internasional ini pada hakikatnya rnencakup perkembangan dalam pelbagai aspek ilmu pengetahuan modern tentang kejahatan (modern criminal science) baik dalam kebijakan pidana (penal policy), kriminologi maupun dalam bidang hukum pidana (Muladi, 1990). 
Demikian pula dengan rumusan "tindak pidana perkosaan" yang ada dalam Rancangan KUHP Baru. Di mana kebijakannya tampak dipengaruhi oleh perkembangan-perkembangan di atas. Tindak perkosaan yang menjadikan wanita sebagai korbannya, merupakan salah satu bentuk kejahatan kekerasan terhadap wanita. Perwujudan yang lain berupa pemerasan, penganiayaan, atau pembunuhan dan sebagainya. Masalah kekerasan terhadap wanita saat itu, bukan hanya merupakan masalah individual atau nasional, tetapi sudah menjadi masalah global.

Dibanding jenis kejahatan kekerasan lainnya, perkosaan merupakan jenis kejahatan kekerasan terhadap wanita yang paling mencemaskan, bukan saja bagi wanita, akan tetapi juga masyarakat dan kemanusiaan. Karena itulah, kejahatan perkosaan paling potensial menimbulkan terciptanya tingkat "fear of crime" (ketakutan terhadap kejahatan) masyarakat yang tinggi, dibanding jenis kejahatan kekerasan lainnya (Mulyana, 1988).

Di samping itu juga disebut sebagai masalah global karena terkait dengan issue global tentang hak-hak asasi manusia (HAM), yang per definisi diartikan sebagai hak-hak yang melekat (inherent) secara alamiah sejak manusia dilahirkan dan tanpa itu manusia tidak dapat hidup sebagai manusia secara wajar.

Kaitan dengan HAM tampak dari pelbagai pernyataan antara lain bahwa kekerasan terhadap wanita merupakan rintangan (barrier) terhadap pembangunan, karena dengan demikian akan mengurangi kepercayaan diri dari wanita, menghambat kemampuan wanita untuk berpartisipasi penuh dalam kegiatan sosial, rnengganggu Kesehatan wanita, mengurangi otonomi wanita baik dalam bidang ekonomi, politik sosial budaya dan fisik. Dengan demikian kemampuan wanita untuk memanfaatkan kehidupannya baik fisik, ekonomi, politik dan kultural menjadi terganggu (Muladi 1997). Dalam pelbagai pertemuan internasional, di antaranya Konferensi Internasional HAM PBB di Wina pada tahun 1993, mengakui kekerasan terhadap wanita adalah sebagai pengingkaran HAM wanita. 
Selain dari itu perlu bercermin pada upaya perekayasaan hukum dalam mengantisipasi masalah kejahatan perkosaan di Amerika Serikat yang memerlukan kurang lebih duapuluh tahun sejak dimulainya gerakan feminisme sekitar tahun 1960-an.

Gerakan untuk memperjuangkan undang-undang perkosaan ini dipelopori dan didukung oleh, "The Feminist Group", "Victims Rights Group" dan organisasi pendukung "Law and Orde" telah membangkitkan suatu gerakan pembaruan atas Undang-undang perkosaan (Rape Law Reform) di negara ini (Atmasasmita, 1995).

Sedangkan masalah hukum yang dikemukakan oleh gerakan pembaruan ini adalah:

1. Pelaku perkosaan tidak ditangkap dan dikenakan penahanan karena kebanyakan korban enggan untuk melaporkan perbuatan tersebut;

2. Banyak pelaku perkosaan yang ditangkap atau ditahan, tidak dituntut atau dituntut hanya untuk suatu pelanggaran ringan sebab sering korban perkosaan yang kemudian diadili daripada si pelaku (perkosaan);

3. Banyak pelaku perkosaan dikenal oleh korbannya sehingga masyarakat umum tidak melihat viktimisasi oleh pacar atau tunangan si korban sesungguhnya sebagai suatu perkosaan.

Hasil dari pembaruan undang-undang tentang perkosaan adalah lahirlah Rule 412 dari undang-undang (pembuktian) Federal di Amerika Serikat tahun 1978. Sementara di Indonesia, issue sentralnya hingga hari ini tetap tak beranjak dari lemahnya hukum dalam memberikan perlindungan hukum bagi wanita korban perkosaan, yang tampak dari rendahnya ancaman hukuman bagi pelaku pemerkosaaan (Pasal 285 KUHP) yakni setinggi - tingginya 12 tahun penjara. Di dalam praktik hingga hari ini belum ada pengadilan di Indonesia yang menjatuhkan maksimal itu pada pelaku perkosaan.

Dari uraian di atas semakin menjadi jelas bahwa pergeseran pandangan telah terjadi secara drastis. Semula masalah kekerasan terhadap wanita 
(perkosaan) dilihat sebagai bentuk kejahatan biasa. Namun dalam perkembangannya kemudian tampak bahwa kekerasan terhadap wanita (perkosaan) tidak hanya merupakan persoalan yuridis semata. Dibelakangnya ada suatu spirit yang besar yang berkaitan dengan HAM.

Demikian pula dengan rumusan "tindak pidana perkosaan" yang ada dalam Rancangan KUHP Baru, kebijakannya tampak dipengaruhi oleh pandangan di atas, sehingga pengertian perkosaan jauh lebih luas dibanding dengan Pasal 285 KUHP. Hal ini dapat diketahui dari ungkapan Muladi sebagai salah seorang anggota Tim Perancang KUHP Baru yang menuliskan dalam salah satu makalahnya Penataran Nasional Hukum Pidana dan Kriminologi pada tanggal 8-23 November 1993 di Semarang sebagai berikut:

Dibanding dengan perkembangan di pelbagai negara, maka perumusan tindak pidana perkosaan di dalam KUHP sudah tidak sesuai lagi dengan perkembangan sosial. Masalah perkosaan tidak lagi dilihat sebagai persoalan moral semata-mata (moral offence), namun di dalamnya terkait masalah anger and violence yang dianggap merupakan pelanggaran dan pengingkaran hak-hak asasi manusia.

Ungkapan di atas menunjukkan, bahwa pertimbangan dan pola pikir pembuat Rancangan KUHP Baru dalam merumuskan tindak pidana perkosaan sebagai suatu kebijakan hukum pidana tidak lagi terbatas pada masalah penegakan moral semata, tetapi sudah menjangkau lebih jauh lagi yaitu yang berkait dengan masalah perlindungan hak-hak asasi manusia khususnya bagi wanita.

\section{Rumusan Tindak Pidana Perkosaan dalam KUHP dan Rancangan KUHP beserta Implikasinya.}

Dalam pandangan KUHP seorang yang melakukan persetubuhan di luar perkawinan dengan dasar suka rela pada prinsipnya tidak di pidana. Kemudian yang dapat dipidana menurut KUHP, hanya jika persetubuhan di luar perkawinan itu dilakukan secara paksa atau perkosaan (verkrachting). 
Tentang perkosaan ini telah diatur dalam Pasal 285 KUHP yang rumusannya berbunyi sebagai berikut: "Barang siapa dengan kekerasan atau ancaman kekerasan memaksa seorang wanita bersetubuh dengan dia di luar perkawinan, diancam karena melakukan perkosaan dengan pidana penjara paling lama dua belas tahun".

Jadi yang diancam pidana dalam pasal tersebut adalah melakukan dengan kekerasan atau ancaman kekerasan memaksa wanita yang bukan istrinya untuk bersetubuh dengan dia. Kata memaksa berarti, melakukan tekanan pada orang, sehingga orang itu melakukan sesuatu yang berlawanan dengan kehendak dirinya (Soesilo, 1981).

Untuk dapat dituntut menurut pasal ini, persetubuhan yang dipaksa tersebut harus benar-benar terjadi, artinya kelamin laki-laki masuk ke dalam lubang kelamin wanita, sehingga mengeluarkan sperma. Tetapi apabila tidak terjadi yang demikian, mungkin perbuatannya itu akan terjaring Pasal 289 KUHP, yaitu memaksa dengan kekerasan atau ancaman kekerasan untuk berbuat cabul. Seperti yang disebutkan dalam H.R. 5 Pebruari 1912, W.9292: "persetubuhan di luar antara kelaminkelamin laki-laki dan wanita semata-mata, bukanlah merupakan persatuan dari alat-alat kelamin tersebut seperti yang disyaratkan untuk suatu perkosaan" (Lamintang, 1990).

Dalam Pasal 285 KUHP ini, pembuat undang-undang ternyata menganggap tidak perlu untuk menentukan pidana bagi wanita yang memaksa untuk bersetubuh, bukanlah semata-mata oleh karena paksaan seorang wanita terhadap orang laki-laki itu dipandang tidak mungkin, akan tetapi justru karena perbuatan itu bagi laki-laki dipandang tidak mengakibatkan sesuatu yang buruk atau yang merugikan. Melainkan karena seorang wanita ada bahaya untuk hamil dan melahirkan anak oleh karena itu (Soesilo, 1981).

Bertolak dari rumusan Pasal 285 KUHP beserta segala implikasinya, maka rumusan tindak pidana perkosaan dalam Rancangan KUHP Baru mengalami perkembangan dan perluasan sedemikian rupa di antaranya 
ialah terjadinya persetubuhan dengan paksaan bukanlah satu-satunya syarat untuk adanya tindak pidana perkosaan.

Pertimbangan kemungkinan akan "mengandung atau hamil" akibat dari perkosaan tidak lagi dipandang yang paling penting dan dominan, karena pengertian persetubuhan (sexual intercourse) saat ini sudah bergeser tidak semata-mata adanya peraduan dua anggota kelamin laki dan wanita, akan tetapi dapat pula bersifat anal dan oral. Bahkan mencakup pula perbuatan berupa memasukan benda-benda yang bukan organ tubuh yang dimanipulasikan ke dalam vagina atau anus seseorang wanita disamakan dengan perkosaan.

Di samping itu perkembangan pengertian perkosaan perlu diperinci, yakni mencakup apa yang dinamakan forcible rape dan statutory rape yang diarahkan kepada perlindungan terhadap gadis yang masih muda (di bawah usia tertentu), yang secara hukum dianggap belum mempunyai kemampuan untuk menentukan kehendaknya. Dalam hal ini "Willing participation by victim is no defence". Kemungkinan persetubuhan yang dilakukan dengan persetujuan wanita tetapi dengan unsur penipuan perlu pula diperhitungkan (Muladi, 1993).

Sehubungan dengan perkembangan dan perluasan pola pikir tentang ruang lingkup tindak pidana perkosaan di atas, maka rumusan Pasal 285 KUHP dalam Rancangan KUHP Baru diadakan perubahan dan penyempurnaan yang diletakkan dalam Pasal 423 yang berbunyi :

1. Dipidana karena melakukan tindak pidana perkosaan, dengan pidana penjara paling lama 12 (dua belas) tahun dan paling singkat 3 (tiga) tahun:

a. laki-laki yang melakukan persetubuhan dengan perempuan di luar perkawinan, bertentangan dengan kehendak perempuan tersebut;

b. laki-laki yang melakukan persetubuhan dengan perempuan di luar perkawinan, tanpa persetujuan perempuan tersebut;

c. laki-laki yang melakukan persetubuhan dengan perempuan, dengan persetujuan perempuan tersebut, tetapi persetujuan tersebut dicapai melalui ancaman untuk dibunuh atau dilukai; 
d. laki-laki yang melakukan persetubuhan dengan perempuan, dengan persetujuan perempuan tersebut karena perempuan tersebut percaya bahwa laki-laki tersebut adalah suaminya yang sah;

e. laki-laki yang melakukan persetubuhan dengan perempuan yang berusia di bawah 14 (empat belas) tahun, dengan persetujuannya; atau

f. laki-laki yang melakukan persetubuhan dengan perempuan, padahal diketahui bahwa perempuan tersebut dalam keadaan pingsan atau tidak berdaya.

2. Dianggap juga melakukan tindak pidana perkosaan, jika dalam keadaan sebagaimana dimaksud dalam ayat (1) :

a. laki-laki memasukkan alat kelaminnya ke dalam anus atau mulut perempuan; atau

b. laki-laki memasukkan suatu benda yang bukan merupakan bagian tubuhnya ke dalam vagina atau anus perempuan.

Walaupun dalam rumusan ayat (l)-nya pasal di atas butir-butirnya ada yang dapat ditafsirkan secara implisit bahwa perkosaan dapat dilakukan terhadap istri dalam hubungan perkawinan (dikenal dengan istilah "marital rape"), namun hal ini telah ditegaskan dalam penjelasan Pasal 423 undang-undang ini, bahwa daiam perkawinan tidak dapat terjadi perkosaan oleh suami terhadap istrinya.

Begitu pula pada rumusan ayat (1) f tampak merupakan adopsi dari Pasal 286 KUHP, hanya bedanya terletak pada implikasi hubungan perbuatan pelaku dengan pingsan atau tidak berdayanya korban. Artinya untuk dapat dikenai Pasal 286 KUHP tersebut, timbulnya keadaan pingsan atau tidak berdayanya pada perempuan (korban) itu bukan pelaku yang membuatnya, namun sebaiknya jika pelaku yang membuatnya, maka perbuatannya itu akan menjadi tindak pidana perkosaan (Pasal 285). Sedang dalam pandangan Rancangan KUHP Baru (Pasal 423) apakah yang membuat pingsan atau tidak berdayanya perempuan itu si pelaku atau bukan tidak lagi menjadi alasan pembeda untuk dapatnya dikenai pasal perkosaan. 
Kemudian selain perbandingan rumusan dan segi "perbuatan pelaku" beserta implikasinya antara Pasal 285 KUHP dengan Pasal 423 Rancangan KUHP Baru yacg diuraikan diatas, selanjutnya yang menarik untuk diperhatikan adalah masalah ancaman pidananya beserta efeknya.

Dalam rumusan Pasal 285 KUHP tersebut, ancaman pidananya adalah maksimal 12 tahun penjara. Dalam hal ini rumusan pasal tersebut tidak memberikan alternatif artinya hanya ada satu pidana pokok yang diancamkan terhadap pelaku kejahatan perkosaan tanpa disebut batas minimalnya. Karena itu dalam pelaksanaan penjatuhan pidana tersebut tinggal tergantung kepada kebebasan hakim untuk menentukan berat ringannya pidana yang akan dijatuhkan.

Bertolak dari ancaman pidana yang ada pada Pasal 285 KUHP maka lain pula yang dirumuskan dalam Pasal 423 Rancangan KUHP Baru yang selain memberikan batasan maksimal 12 (dua belas) tahun penjara juga memberikan batas minimal yaitu 3 (tiga) tahun penjara. Sehingga dengan demikian diharapkan dapat menjamin rasa keadilan dan menghindarkan adanya disparitas yang mencolok dalam kasus yang sebanding.

Perkembangan lain yang menarik dalam ancaman pidana ini ialah, apabila perkosaan berakibat luka berat atau berakibat mati, pidana minimalnya menjadi 5 (lima) tahun penjara dan maksimainya menjadi 15 (lima belas) tahun penjara (Pasal 426 ayat (1) Rancangan KUHP Baru). Perlu dikemukakan, bahwa di dalam KUHP tidak ada perumusan yang eksplisit mengenai perkosaan yang berakibat luka berat.

\section{Simpulan}

Politik hukum pidana dapat mencakup kebijakan di bidang hukum pidana material, formil dan bidang hukum pelaksanaan pidana. Uraian di atas lebih banyak menitik beratkan pada kebijakan di bidang hukum pidana material (substansif), terutama dari sisi perumusan yang menyangkut masalah kriminalisasi dan dekriminalisasi sebagai suatu wujud dari pelaksanaan politik hukum pidana, sebagaimana disebutkan 
oleh Sudarto yakni usaha untuk mewujudkan peraturan-peraturan hukum pidana yang baik sesuai dengan keadaan dan situasi pada suatu saat.

Terkait dengan itu, kenyataan menunjukkan bahwa pengertian kejahatan perkosaan telah berkembang sehingga perlu dirumuskan dalam Rancangan KUHP Baru dalam bentuk yang lebih luas dibanding KUHP. Pemerkosaan bukan lagi semata-mata persoalan moral tetapi sudah bergeser menembus pada persoalan hak asasi manusia khususnya wanita yang perlu mendapat perlindungan secara hukum. 


\section{Daftar Pustaka}

Departemen Hukum dan Perundang-undangan. Rancangan KUHP.

M.W Kusumah. 1988. Kejaliatan dan Penyimpangan Suatu Perspektif Kriminologi. Jakarta: YLBHI.

Muladi. 1990. Proyeksi Hukum Pidana Materiil Indonesia di Masa Datang. Pidato Pengukuhan Guru Besar, tanggal 24 Februari 1990 di Undip. . 1993. Perkembangan Pengaturan Tindak Pidana Dalam KUHP Mendatang, Makalah disampaikan pada Penataran Nasional Hukum

Pidana dan Kriminologi, tanggal 8-23 November 1993'di Undip Semarang.

. 1997. Hak Asasi Manusia, Politik dan Sistem Peradilan Pidana, Semarang: Undip.

P.A.F Lamintang. 1990. Hukum Pidana Indonesia, Bandung: Sinar Baru.

R Soesilo. 1981. Kitab Undang-Undang Hukum Pidana (KUHP). Bogor: Politea.

Romli Atmasasmita. 1995. Pelecehan Seksual. Penyunting Suparmaan Marzuki. dkk. Yogyakarta: FH. UII.

Sudarto. 1983. Hukum Pidana dan Perkembangan Masyarakat. Bandung: Sinar Baru. 